\title{
Impact of the Supramolecular Organisation of Pyrene - Quinoline Conjugates on their Interaction with ds - DNA
}

\author{
Iva Orehovec, ${ }^{2}$ Danijel Glavač, ${ }^{1}$ Irena Doklii, ${ }^{3}$ Matija Gredičak, ${ }^{1}$ Ivo Piantanida $*, 2$
}

\footnotetext{
1 Laboratory for Biomimetic Chemistry, Division of Organic Chemistry and Biochemistry, Ruđer Bošković Institute, Bijenička c. 54, HR-10000, Zagreb, Croatia

2 Laboratory for Biomolecular Interactions and Spectroscopy, Division of Organic Chemistry and Biochemistry, Ruđer Bošković Institute, Bijenička c. 54, HR-10000, Zagreb, Croatia

3 Laboratory for stereoselective catalysis and biocatalysis, Division of Organic Chemistry and Biochemistry, Ruđer Bošković Institute, Bijenička c. 54, HR-10000, Zagreb, Croatia

* Corresponding author's e-mail address: pianta@irb.hr
}

RECEIVED: December 11, 2017 * REVISED: February 14, 2018 * ACCEPTED: March 26, 2018

THIS PAPER IS DEDICATED TO PROF. MLADEN ŽINIĆ ON THE OCCASION OF HIS 70 $70^{\text {Th }}$ BIRTHDAY

\begin{abstract}
Two novel pyrene - quinoline conjugates differing in the linker flexibility between aryls were prepared. In comparison with referent pyrene derivative, both conjugates showed intramolecular pyrene - quinoline stacking in aqueous medium, much more efficient for rigid conjugate. Consequently, only rigid conjugate showed excimer fluorescence with exceptionally strong bathochromic shift (+ $55 \mathrm{~nm}$ ) of emission maximum in respect to referent pyrene analogue and flexible conjugate. All studied compounds showed similar, $10 \mu \mathrm{mol} \mathrm{dm}^{-3}$ affinity toward ds - DNA, characterised in general by fluorescence quenching. The flexible conjugate showed at large excess of DNA over dye formation of pyrene - quinoline excimer, while rigid conjugate retained excimer emission throughout all DNA concentrations. Lack of significant thermal stabilisation of ds - DNA by studied compounds and minor changes in CD spectrum of DNA supported non - specific agglomeration of both conjugates and referent pyrene analogue within hydrophobic DNA grooves as the dominant binding mode.
\end{abstract}

Keywords: pyrene, quinoline, fluorescence, DNA recognition, excimer emission.

\section{INTRODUCTION}

$\mathbf{S}$ MALL molecules which could selectively report on small structural differences of DNA as well as RNA secondary structure or their higher ordered structures are of significant scientific interest as molecular tools and probes. ${ }^{[1]}$ There are several dominant non - covalent binding modes of small molecule to ds - DNA / RNA: intercalation, groove binding and electrostatic interactions with negatevely charged phosphate backbone, each of them with certain advantages and pitfalls. Therefore, many researchers designed molecules combining two or more dominant binding interactions aiming toward improved selectivity.

One of the extensively used polarity - sensitive probes is pyrene: its fluorescence has been employed for the characterisation of micro - heterogeneous systems. ${ }^{[2]} \mathrm{A}$ long lifetime of the excited state and the possibility of easy excimer formation ${ }^{[3]}$ are distinctive features of the pyrene fluorophore that allow its application for detection of nucleic acid interactions both as a single labe ${ }^{[4]}$ and in excimer - forming pairs or as multi - pyrene probes. ${ }^{[5]}$ Moreover, the flat aromatic structure of the pyrene residue facilitates its stacking with nucleobases. ${ }^{[6]}$ However, intercalative binding of pyrene to DNA / RNA has very limited selectivity and thus pyrene most interesting applications relied on its interactions within the DNA or RNA grooves ${ }^{[7]}$ or were combined with switch - on and - off of pyrene excimer. ${ }^{[8]}$ The short peptides and peptidomimetics, including condensed aromatic peptide conjugates, could be designed to bind to DNA / RNA, whereby peptide backbone is not only structural component directing DNA - targeting units but also can actively interact within polynucleotide groove by set of hydrogen - bonding and hydrophobic interactions. ${ }^{[9,10]}$

In a search for new small molecules targeting DNA we noted intriguing properties of helical foldamers based 
<smiles>O=C(CNCc1ccc2ccc3cccc4ccc1c2c34)NCC(F)(F)F</smiles>

4

$\mathrm{Mr}=362.40$<smiles>NC(=O)C(=O)OCCCOc1cc(C(=O)NCC(=O)NCc2ccc3ccc4cccc5ccc2c3c45)nc2c([N+](=O)[O-])cccc12</smiles><smiles>CC(C)(C)OC(=O)C(C)(C)OC(=O)NCC(=O)Nc1cc(OCCCNC(=O)c2ccc3ccc4cccc5ccc2c3c45)c2nc([N+](=O)[O-])cccc1-2</smiles>

Scheme 1. Novel pyrene - quinoline conjugates 7, 8 and referent pyrene analogue 4 .

on quinoline amides, which interacted efficiently with DNA. ${ }^{[11]}$ This raised a question whether the heterogeneous conjugate made of pyrene and quinoline would show different DNA binding properties, due to the altered intramolecular folding of two different aromatic moieties. As a preliminary study we prepared two pyrene - quinoline dimers (Scheme 1, 7 and 8) differing slightly in peptide linker length and rigidity to test fine structural impact, and also a referent pyrene analogue 4 for comparison. All derivatives are equipped with positively charged aliphatic amine group for increased water solubility and also additional electrostatic interactions with DNA backbone.

\section{EXPERIMENTAL SECTION}

\section{General Information}

Unless otherwise indicated, solvents were used as supplied (analytical or HPLC grade) without further purification. "Petrol" or "petroleum ether" refers to the fraction of petroleum ether boiling in the range $40-60{ }^{\circ} \mathrm{C}$. Where mixtures of solvents are specified, the stated ratios are volume: volume. Unless otherwise indicated, all aqueous solutions used were saturated. Reagents were used directly as supplied by major chemical suppliers.

Flash column chromatography was carried out using silica gel (Merck, 40-63 $\mu \mathrm{m}$ particle size). Analytical thin layer chromatography was carried out on Merck Kieselgel

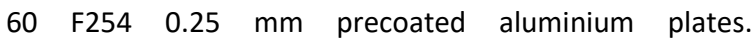
Visualization was carried out under ultra - violet irradiation $(254 \mathrm{~nm})$ and by appropriate heating with ammonium molybdate. Ammonium molybdate solution was prepared by dissolving ammonium molybdate $(5 \mathrm{~g})$ and ceric sulfate $(0.2 \mathrm{~g})$ in $5 \%$ aqueous sulfuric acid $(100 \mathrm{~mL})$.

NMR spectra were recorded on Bruker Avance 600 $\mathrm{MHz}$ and $300 \mathrm{MHz}$ spectrometers, operating at 150.92 or $75.47 \mathrm{MHz}$ for ${ }^{13} \mathrm{C}$ and 600.13 or $300.13 \mathrm{MHz}$ for ${ }^{1} \mathrm{H}$ nuclei. Chemical shifts are quoted in ppm, and are referenced to the residual non - deuterated solvent peak. ${ }^{1} \mathrm{H}$ spectra are reported as follows: ${ }^{1} \mathrm{H}$ NMR (spectrometer frequency, solvent): $\delta$ chemical shift / ppm (multiplicity, number of protons, $J$ - coupling constant(s), assignment). ${ }^{13} \mathrm{C}$ spectra are reported as follows: ${ }^{13} \mathrm{C}$ NMR (spectrometer frequency, solvent): $\delta$ chemical shift / ppm (assignment). Multiplets are abbreviated as follows: $\mathrm{s}$ - singlet; $\mathrm{d}$ - doublet; $\mathrm{t}$ triplet; $q$ - quartet; $m$ - multiplet, and are reported based on appearance rather than interpretation. Compound multiplets are reported in the order of decreasing coupling constant magnitude. Spectra were acquired at $298 \mathrm{~K}$.

Mass spectrometry measurements were performed on HPLC system coupled with triple quadrupole mass spectrometer, operating in a positive electrospray ionization (ESI) mode.

Melting points were determined using an Electrothermal 9100 apparatus in open capillaries and are uncorrected.

Where given, systematic compound names are those generated by ChemBioDraw Ultra 12.0 following IUPAC conventions. Spectral assignment purpose is arbitrary and not necessarily consistent with the IUPAC names (Scheme 2).

Tert-butyl(2-oxo-2-(pyren-2-ylamino)ethyl)carbamate (1) Pyren-2-amine (100 mg, $0.46 \mathrm{mmol}$ ), N-Boc-glycine ( $80 \mathrm{mg}$, $0.46 \mathrm{mmol}$ ) and triethylamine $(77 \mu \mathrm{L}, 0.55 \mathrm{mmol})$ were mixed in DMF $(10 \mathrm{~mL})$ under argon. (Benzotriazol-1yloxy)tris(dimethylamino)phosphonium hexafluorophosphate (BOP reagent, $224 \mathrm{mg}, 0.55 \mathrm{mmol}$ ) was added, and the reaction mixture was stirred overnight at room temperature. Saturated aqueous solution of $\mathrm{NH}_{4} \mathrm{Cl}(10 \mathrm{~mL})$ was added, and the mixture extracted with diethyl ether ( 3 $\times 5 \mathrm{~mL}$ ). Organic layers were combined, dried over $\mathrm{Na}_{2} \mathrm{SO}_{4}$, filtered and concentrated under reduced pressure. The product was obtained by flash column chromatography in dichloromethane - methanol $1: 0 \rightarrow 20: 1$ as a brown solid. 


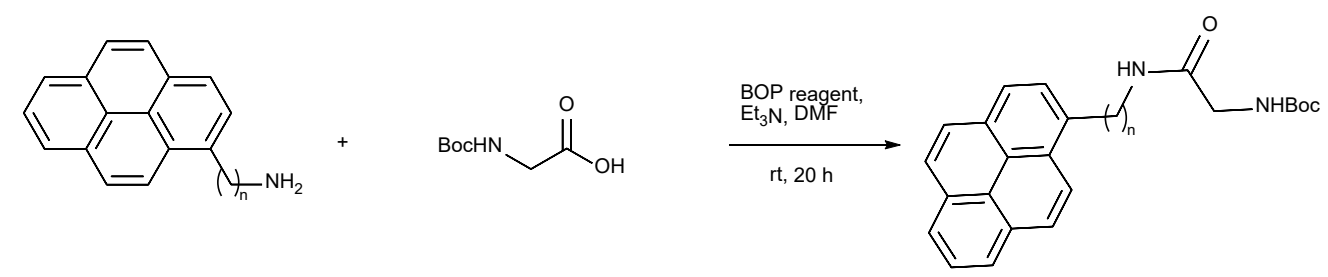

1) $\mathrm{n}=\mathbf{0}, \mathrm{i}=\mathbf{5 0} \%$

2) $\mathrm{n}=1, \mathrm{i}=95 \%$

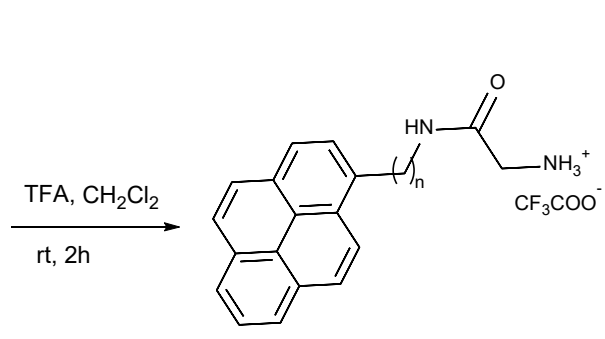

3) $\mathrm{n}=\mathbf{0}, \mathrm{R}=\mathrm{H}, \mathrm{i}=\mathbf{9 4} \%$

4) $\mathrm{n}=1, \mathrm{R}=\mathrm{H}, \mathrm{i}=95 \%$

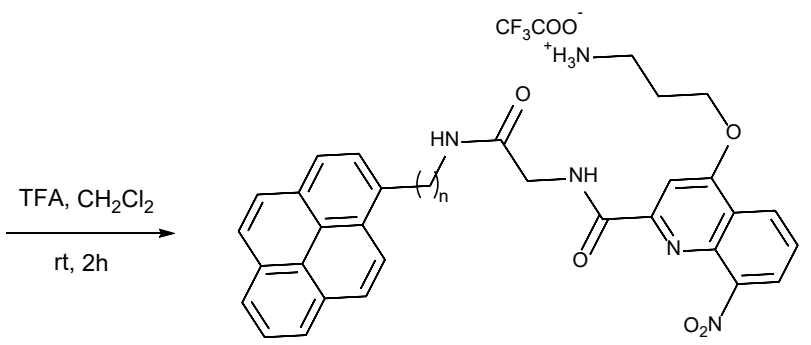

7) $\mathbf{n}=\mathbf{0}, \mathrm{i}=\mathbf{8 5} \%$

8) $\mathrm{n}=1, \mathrm{i}=92 \%$

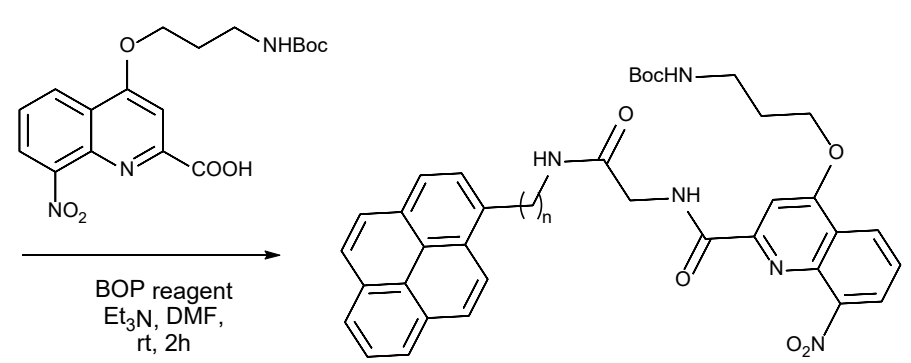

5) $\mathrm{n}=0, \mathrm{i}=56 \%$

6) $\mathrm{n}=1, \mathrm{i}=60 \%$

Scheme 2. Synthesis of pyrene conjugates $4,7,8$.

Yield: $85 \mathrm{mg}(50 \%)$. m.p. $159-161^{\circ} \mathrm{C} .{ }^{1} \mathrm{H}$ NMR $(600 \mathrm{MHz}$, $\mathrm{CDCl}_{3}$ ) $\delta / \mathrm{ppm}: 9.06(\mathrm{~s}, 1 \mathrm{H}), 8.18(\mathrm{~d}, J=6.5 \mathrm{~Hz}, 1 \mathrm{H}), 8.02(\mathrm{~d}$, $J=7.4 \mathrm{~Hz}, 1 \mathrm{H}), 7.93(\mathrm{~d}, J=7.4 \mathrm{~Hz}, 1 \mathrm{H}), 7.87(\mathrm{t}, J=6.4 \mathrm{~Hz}$, $1 \mathrm{H}), 7.82(\mathrm{~m}, 3 \mathrm{H}), 7.74(\mathrm{~m}, 2 \mathrm{H}), 5.76(\mathrm{t}, J=5.7 \mathrm{~Hz}, 1 \mathrm{H}), 4.15$ $(\mathrm{s}, 2 \mathrm{H}), 1.54(\mathrm{~s}, 9 \mathrm{H}) .{ }^{13} \mathrm{C} \mathrm{NMR}\left(75 \mathrm{MHz}, \mathrm{CDCl}_{3}\right) \delta / \mathrm{ppm}: 169.0$, $156.9,131.1,130.5,129.7,128.9,127.6,127.0,126.6$, 125.9, 125.2, 124.8, 124.7, 124.4, 123.2, 121.7, 120.2, 80.8, 45.8, 28.4. ESI-MS: $m / z 375\left[\mathrm{M}+\mathrm{H}^{+}\right]^{+}$.

\section{Tert-butyl(2-oxo-2-((pyren-1-ylmethyl)ami- no)ethyl)carbamate (2)}

Pyren-2-ylmethanamine (100 mg, $0.37 \mathrm{mmol}), \quad N$-Bocglycine ( $65 \mathrm{mg}, 0.37 \mathrm{mmol}$ ) and triethylamine $(115 \mu \mathrm{L}, 0.82$ mmol) were mixed in DMF $(10 \mathrm{~mL})$ under argon. (Benzotriazol-1-yloxy)tris(dimethylamino)phosphonium hexafluorophosphate (BOP reagent, $181.5 \mathrm{mg}, 0.41 \mathrm{mmol}$ ) was added, and the reaction mixture was stirred overnight at room temperature. Saturated aqueous solution of $\mathrm{NH}_{4} \mathrm{Cl}$
$(10 \mathrm{~mL})$ was added, and the mixture extracted with diethyl ether $(3 \times 5 \mathrm{~mL})$. Organic layers were combined, dried over $\mathrm{Na}_{2} \mathrm{SO}_{4}$, filtered and concentrated under reduced pressure. The product was obtained by flash column chromatography in ethyl acetate - petroleum ether $1: 1$ as a yellow solid. Yield: 136 mg (95 \%). m.p. $164-167{ }^{\circ} \mathrm{C} .{ }^{1} \mathrm{H}$ NMR $(600 \mathrm{MHz}$, $\left.\mathrm{CDCl}_{3}\right) \delta / \mathrm{ppm}: 8.16(\mathrm{~d}, J=7.6 \mathrm{~Hz}, 3 \mathrm{H}), 8.11-8.06(\mathrm{~m}, 2 \mathrm{H})$, $8.05-7.97(\mathrm{~m}, 3 \mathrm{H}), 7.89(\mathrm{~d}, J=7.7 \mathrm{~Hz}, 1 \mathrm{H}), 6.60(\mathrm{~s}, 1 \mathrm{H}), 5.20$ $(\mathrm{s}, 1 \mathrm{H}), 5.09(\mathrm{~d}, J=5.2 \mathrm{~Hz}, 2 \mathrm{H}), 3.83(\mathrm{~s}, 2 \mathrm{H}), 1.33(\mathrm{~s}, 9 \mathrm{H}) .{ }^{13} \mathrm{C}$ NMR (151 MHz, $\mathrm{CDCl}_{3}$ ) $\delta / \mathrm{ppm}: 169.2,156.1,131.2,130.7$, $130.6,128.9,128.3,127.5,127.3,126.9,126.1,125.4$, $125.3,124.9,124.7,124.6,122.6,80.3,44.5,41.7,28.2$. ESIMS: $m / z 389\left[\mathrm{M}+\mathrm{H}^{+}\right]^{+}$.

\section{2-oxo-2-(pyren-2-ylamino)ethanaminium-2,2,2- trifluoroacetate (3)}

Tert-butyl(2-oxo-2-(pyren-2-ylamino)ethyl)carbamate $\mathbf{1}$ (50 $\mathrm{mg}, 0.13 \mathrm{mmol}$ ) was dissolved in $90 \%$ trifluoroacetic 
acid ( $3 \mathrm{~mL}$ ). Reaction mixture was stirred for 2 hours and then triturated with diisopropyl ether to obtain crude compound 3. Yield: $48 \mathrm{mg}(94 \%)$. m.p. $260-263^{\circ} \mathrm{C}$. ${ }^{1} \mathrm{H}$ NMR (600 MHz, DMSO) $\delta / p p m: ~ 10.80(s, 1 H), 8.38-8.31(\mathrm{~m}, 3 \mathrm{H})$, $8.31-8.25(\mathrm{~m}, 2 \mathrm{H}), 8.24-8.19(\mathrm{~m}, 3 \mathrm{H}), 8.12(\mathrm{t}, J=7.5 \mathrm{~Hz}$, 1H), 4.09 (s, 2H). ${ }^{13} \mathrm{C} \mathrm{NMR} \mathrm{(151} \mathrm{MHz,} \mathrm{DMSO)} \delta / \mathrm{ppm}: 166.4$, $131.3,131.0,130.9,129.1,127.9,127.7,127.4,127.1$, 126.0, 125.6, 125.6, 124.8, 124.4, 124.2, 123.4, 122.6, 41.5 . ESI-MS: $m / z 275\left[\mathrm{M}+\mathrm{H}^{+}\right]^{+}$.

\section{2-oxo-2-((pyren-1-ylmethyl)amino)ethanaminium-2,2,2- trifluoroacetate (4)}

Tert-butyl(2-oxo-2-((pyren-1-ylmethyl)amino)ethyl)carbamate 2 (110 mg, $0.28 \mathrm{mmol}$ ) was dissolved in $90 \%$ trifluoroacetic acid ( $3 \mathrm{~mL}$ ). Reaction mixture was stirred for 2 hours and then triturated with diisopropyl ether to obtain crude compound 4 as brown solid. Yield: $108 \mathrm{mg}$ (95\%). m.p. $214-218{ }^{\circ} \mathrm{C}$. ${ }^{1 \mathrm{H}} \mathrm{NMR}(600 \mathrm{MHz}$, DMSO) $\delta /$ ppm: 9.07 $(\mathrm{s}, 1 \mathrm{H}), 8.37(\mathrm{~d}, J=9.2 \mathrm{~Hz}, 1 \mathrm{H}), 8.35-8.23(\mathrm{~m}, 4 \mathrm{H}), 8.17(\mathrm{~s}$, $2 \mathrm{H}), 8.12(\mathrm{~s}, 2 \mathrm{H}), 8.10-8.04(\mathrm{~m}, 2 \mathrm{H}), 5.09(\mathrm{~d}, J=5.5 \mathrm{~Hz}, 2 \mathrm{H})$, 3.65 (s, 2H). ${ }^{13} \mathrm{C}$ NMR (75 MHz, DMSO) $\delta / p p m: ~ 166.4,132.4$, $131.2,130.7,130.7,128.6,128.2,127.8,127.7,127.28$, $126.8,125.8,125.7,125.2,124.5,124.3,123.6,41.0,40.7$. ESI-MS: $m / z 289\left[\mathrm{M}+\mathrm{H}^{+}\right]^{+}$.

\section{Tert-butyl-(3-((8-nitro-2-((2-oxo-2-(pyren-2 ylamino)ethyl)carbamoyl)quinolin-4- yl)oxy)propyl)carbamate (5)}

4-(3-(tert-Butoxycarbonylamino)propoxy)-8-nitroquinoline-2-carboxylic acid $4^{[11]}(20 \mathrm{mg}, 0.05 \mathrm{mmol})$, compound 3 (20 mg, $0.05 \mathrm{mmol})$, and triethylamine $(20 \mu \mathrm{L}, 0.15 \mathrm{mmol})$ were dissolved in DMF $(2 \mathrm{~mL}$ ) under argon. (Benzotriazol-1yloxy)tris(dimethylami-no)phosphornium hexafluorophosphate (BOP reagent, $24 \mathrm{mg}, 0.05 \mathrm{mmol}$ ) was added, and the reaction was stirred over night at room temperature. Saturated aqueous solution of $\mathrm{NH}_{4} \mathrm{Cl}(10 \mathrm{~mL})$ was added, and the mixture extracted with diethyl ether - ethyl acetate $1: 1(3 \times 5 \mathrm{~mL})$. Organic extracts were combined, dried over $\mathrm{Na}_{2} \mathrm{SO}_{4}$, filtered and concentrated under reduced pressure. Crude product was purified by column chromatography on silica gel with ethyl acetate petroleum ether - dichloromethane $3: 1: 2$ to afford product 5 as brown oil. Yield: $18 \mathrm{mg}(56 \%) .{ }^{1} \mathrm{H}$ NMR (600 $\left.\mathrm{MHz}, \mathrm{CDCl}_{3}\right) \delta / \mathrm{ppm}: 9.12(\mathrm{~s}, 1 \mathrm{H}), 8.96(\mathrm{~s}, 1 \mathrm{H}), 8.49(\mathrm{~m}, 2 \mathrm{H})$, $8.26(\mathrm{~d}, J=7.8 \mathrm{~Hz}, 1 \mathrm{H}), 8.20-8.11(\mathrm{~m}, 6 \mathrm{H}), 8.00(\mathrm{~m}, 3 \mathrm{H}), 7.85$ $(\mathrm{s}, 1 \mathrm{H}), 7.66(\mathrm{t}, J=8.0 \mathrm{~Hz}, 1 \mathrm{H}), 4.58(\mathrm{~d}, J=6.3 \mathrm{~Hz}, 2 \mathrm{H}), 4.41$ (s, 2H), $3.43(\mathrm{~s}, 2 \mathrm{H}), 2.18(\mathrm{~s}, 2 \mathrm{H}), 1.59(\mathrm{~s}, 9 \mathrm{H}) .{ }^{13} \mathrm{C}$ NMR (75 $\left.\mathrm{MHz}_{1} \mathrm{CDCl}_{3}\right) \delta / \mathrm{ppm}: 167.7,165.4,163.7,163.2,155.9$, $147.8,142.1,139.1,135.5,131.3,130.8,128.1,127.4$, $126.8,126.7,126.7,126.1,125.8,125.4,125.2,125.1$, 125.0, 123.2, 122.7, 121.8, 120.3, 99.9, 77.2, 67.4, 45.5, 37.6, 29.7, 28.4, one aromatic carbon not observed. ESIMS: $648\left[\mathrm{M}+\mathrm{H}^{+}\right]^{+}$.

\section{Tert-butyl-(3-((8-nitro-2-((2-oxo-2-((pyren-1- ylmethyl)amino)ethyl)carbamoyl)quinolin-4- yl)oxy)propyl)carbamate (6)}

4-(3-(tert-Butoxycarbonylamino)propoxy)-8-nitroquinoline-2-carboxylic acid $4^{[11]}$ (13 $\mathrm{mg}, 0.03 \mathrm{mmol}$ ), compound 10 (13 mg, $0.03 \mathrm{mmol}$ ), and triethylamine $(14 \mu \mathrm{L}, 0.10$ $\mathrm{mmol})$ were dissolved in DMF $(2 \mathrm{~mL})$ under argon. (Benzotriazol-1-yloxy)tris(dimethylamino)phosphonium hexafluorophosphate (BOP reagent, $16 \mathrm{mg}, 0.04 \mathrm{mmol}$ ) was added, and the reaction was stirred over night at room temperature. Saturated aqueous solution of $\mathrm{NH}_{4} \mathrm{Cl}(10 \mathrm{~mL})$ was added, and the mixture extracted with diethyl ether ethyl acetate 1: $1(3 \times 5 \mathrm{~mL})$. Organic extracts were combined, dried over $\mathrm{Na}_{2} \mathrm{SO}_{4}$, filtered and concentrated under reduced pressure. Crude product was purified by column chromatography on silica gel with ethyl acetate - petroleum ether - dichloromethane $3: 1: 2$ to afford product 6 as yellow oil. Yield: $13 \mathrm{mg}(60 \%) .{ }^{1} \mathrm{H}$ NMR (600 MHz, DMSO) $\delta / p p m: 8.79-8.73(\mathrm{~m}, 2 \mathrm{H}), 8.47(\mathrm{dd}, J=8.4,1.2 \mathrm{~Hz}, 1 \mathrm{H}), 8.40$ (d, $J=9.2 \mathrm{~Hz}, 1 \mathrm{H}$ ), 8.37 (dd, $J=7.5,1.3 \mathrm{~Hz}, 1 \mathrm{H}), 8.32-8.24$ $(\mathrm{m}, 4 \mathrm{H}), 8.17(\mathrm{~m}, 2 \mathrm{H}), 8.12-8.05(\mathrm{~m}, 2 \mathrm{H}), 7.84-7.78(\mathrm{~m}, 1 \mathrm{H})$, $7.72(\mathrm{~s}, 1 \mathrm{H}), 6.97(\mathrm{t}, J=5.3 \mathrm{~Hz}, 1 \mathrm{H}), 5.08(\mathrm{~d}, J=5.7 \mathrm{~Hz}, 2 \mathrm{H})$, $4.41(\mathrm{t}, J=6.1 \mathrm{~Hz}, 2 \mathrm{H}), 4.13(\mathrm{~d}, J=5.7 \mathrm{~Hz}, 2 \mathrm{H}), 3.21(\mathrm{dd}, J=$ 12.5, 6.3 Hz, 2H), 2.05-1.99 (m, 2H), $1.34(\mathrm{~s}, 9 \mathrm{H}) .{ }^{13} \mathrm{C} \mathrm{NMR}$

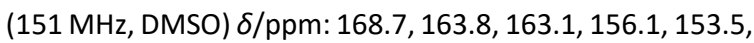
$148.2,138.6,133.1,131.3,130.8,130.6,128.5,128.1$, $127.9,127.5,127.1,126.8,126.7,126.5,125.7,125.6$, $125.4,125.2,124.5,124.4,123.6,122.8,100.6,78.0,67.8$,

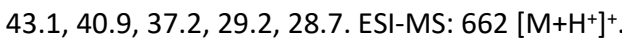

3-((8-nitro-2-((2-oxo-2-(pyren-2-

\section{ylamino)ethyl)carbamoyl)quinolin-4-yl)oxy)propan-1-} aminium-2,2,2-trifluoroacetate (7)

Compound 5 (10 mg, $0.02 \mathrm{mmol}$ ) was dissolved in $90 \%$ trifluoroacetic acid ( $3 \mathrm{~mL}$ ). Reaction mixture was stirred for 2 hours and then triturated with diisopropyl ether to obtain crude compound 7 as grey solid. Yield: 9 mg (85\%). m.p.

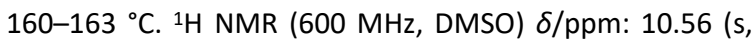
$1 \mathrm{H}), 8.94(\mathrm{~s}, 1 \mathrm{H}), 8.54(\mathrm{~d}, J=8.5 \mathrm{~Hz}, 1 \mathrm{H}), 8.40(\mathrm{~m}, 2 \mathrm{H}), 8.30$ $(\mathrm{t}, J=7.2 \mathrm{~Hz}, 3 \mathrm{H}), 8.25(\mathrm{~d}, J=9.2 \mathrm{~Hz}, 1 \mathrm{H}), 8.22-8.13(\mathrm{~m}, 2 \mathrm{H})$, $8.09(\mathrm{t}, J=7.6 \mathrm{~Hz}, 1 \mathrm{H}), 7.89-7.76(\mathrm{~m}, 4 \mathrm{H}), 4.60-4.39(\mathrm{~m}$, $4 \mathrm{H}), 3.12(\mathrm{~d}, J=6.1 \mathrm{~Hz}, 2 \mathrm{H}), 2.23(\mathrm{~m}, 2 \mathrm{H}) .{ }^{13} \mathrm{C}$ NMR $(151$ $\mathrm{MHz}$, DMSO) $\delta / \mathrm{ppm}: 168.6,166.1,163.9,162.9,158.3$, 148.2 , 138.6, 138.0, 131.3, 130.9, 128.8, 127.7, 127.7, $127.6,127.6,127.1,127.1,126.9,126.9,125.8,125.5$, $125.4,124.8,124.3,122.8,122.7,100.9,67.0,43.7,36.7$, 26.9. ESI-MS: $m / z 548\left[\mathrm{M}+\mathrm{H}^{+}\right]^{+}$

3-((8-nitro-2-((2-oxo-2-)((pyren-1ylmethyl)amino)ethyl)carbamoyl)quinolin-4-

yl)oxy)propan-1-aminium-2,2,2-trifluoroacetate (8) Compound 6 (10 mg, $0.02 \mathrm{mmol}$ ) was dissolved in $90 \%$ trifluoroacetic acid ( $3 \mathrm{~mL}$ ). Reaction mixture was stirred for 
2 hours and then triturated with diisopropyl ether to obtain crude compound 8 as grey solid. Yield: $8 \mathrm{mg}(95 \%)$. m.p. 164-167 ${ }^{\circ} \mathrm{C} .{ }^{1} \mathrm{H}$ NMR ( $\left.600 \mathrm{MHz}, \mathrm{DMSO}\right) \delta / \mathrm{ppm}: 8.78(\mathrm{~s}, 2 \mathrm{H})$, $8.52(\mathrm{~d}, J=8.4 \mathrm{~Hz}, 1 \mathrm{H}), 8.40(\mathrm{dd}, J=11.6,8.6 \mathrm{~Hz}, 2 \mathrm{H}), 8.34-$ $8.23(\mathrm{~m}, 4 \mathrm{H}), 8.17(\mathrm{~s}, 2 \mathrm{H}), 8.09(\mathrm{t}, J=7.4 \mathrm{~Hz}, 2 \mathrm{H}), 7.92-7.78$ $(\mathrm{m}, 4 \mathrm{H}), 7.75(\mathrm{~s}, 1 \mathrm{H}), 5.09(\mathrm{~d}, J=5.4 \mathrm{~Hz}, 2 \mathrm{H}), 4.51(\mathrm{t}, J=5.6$ $\mathrm{Hz}, 2 \mathrm{H}), 4.13(\mathrm{~d}, J=5.6 \mathrm{~Hz}, 2 \mathrm{H}), 3.11(\mathrm{~d}, J=5.9 \mathrm{~Hz}, 2 \mathrm{H}), 2.27$ -2.15 (m, 2H). ${ }^{13} \mathrm{C}$ NMR (151 MHz, DMSO) $\delta / p p m: ~ 168.7$, 163.7, 162.9, 153.5, 148.2, 138.6, 133.1, 131.3, 130.8, 130.6, $128.5,128.1,127.8,127.5,127.1,126.9,126.7,126.5,125.7$, 125.6, 125.5, 125.2, 124.5, 124.4, 123.6, 122.7, 100.8, 67.0, 43.0, 40.9, 36.7, 26.9. ESI-MS: $m / z 563\left[\mathrm{M}+\mathrm{H}^{+}\right]^{+}$.

\section{UV-Visible Spectrophotometry, Circular Dichroism (CD) and Fluorescence Spectroscopy}

The UV-Vis spectra were recorded on a Varian Cary 100 Bio or CECIL Aurius 3021 spectrophotometer, fluorescence spectra on a Varian Cary Eclipse fluorescence spectrophotometer and CD spectra were collected with a Jasco J -815 spectropolarimeter at $25^{\circ} \mathrm{C}$ using $1 \mathrm{~cm}$ path quartz cuvettes.

The calf thymus ct - DNA (Sigma - Aldrich, St. Louis, USA) was dissolved in sodium cacodylate buffer, $I=0.05$ $\mathrm{mol} \mathrm{dm}^{-3}, \mathrm{pH}=7$, additionally sonicated and filtered through a $0.45 \mu \mathrm{m}$ filter. The polynucleotide concentration was determined spectroscopically as the concentration of phosphates, which also corresponds to the concentration of mol nucleobase / L. ${ }^{[12]}$ Aqueous solutions of compounds were buffered to $\mathrm{pH}=7$ (sodium cacodylate buffer, $I=0.05$ $\mathrm{mol} \mathrm{dm^{-3 }}$ ). Spectrophotometric titrations were performed at $\mathrm{pH}=7.0$ (sodium cacodylate buffer, $l=0.05 \mathrm{~mol} \mathrm{dm}^{-3}$ ) by adding portions of DNA solution into the solution of the studied compound. The CD experiments were performed by adding aliquots of the aqueous solutions of compounds into the solution of polynucleotide. In fluorimetric experiments the excitation wavelength above $300 \mathrm{~nm}\left(\lambda_{\text {exc }}\right.$ $=343 \mathrm{~nm}$ ) was used to avoid the possible inner filter effect caused by increasing absorbance of the polynucleotide.

\section{Thermal Denaturation Experiments}

Thermal denaturation experiments for ct - DNA and its complexes with studied compounds were carried out by following the change in the absorption at $260 \mathrm{~nm}$ as a function of temperature. The absorbance of the ligands was subtracted from each curve and the absorbance scale was normalized. $T_{\mathrm{m}}$ values are the midpoints of the transition curves, determined from the maximum of the first derivative and checked graphically by the tangent method. ${ }^{[13]}$ The $\Delta T_{\mathrm{m}}$ values were calculated subtracting $T_{\mathrm{m}}$ of the free nucleic acid from $T_{\mathrm{m}}$ of the complex. The $\Delta T_{\mathrm{m}}$ values (error $\pm 0.5^{\circ} \mathrm{C}$ ) reported are the average of at least duplicate measurements.

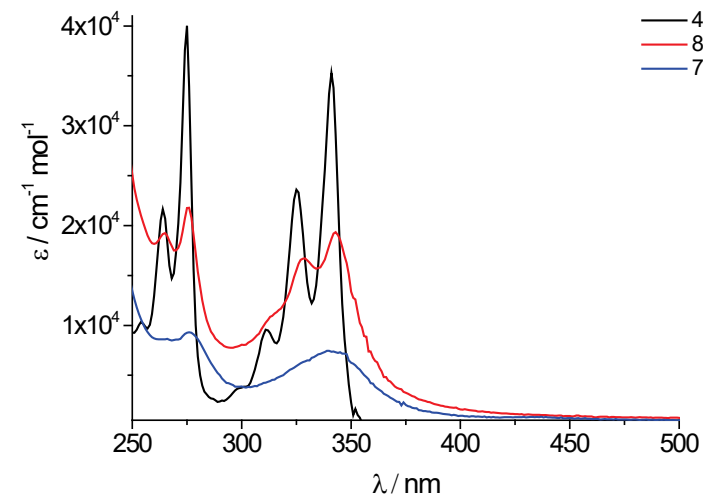

Figure 1. UV-Vis spectra of $4,7,8$ at $c=1 \times 10^{-6} \mathrm{~mol} \mathrm{dm}^{-3}$, in water.

\section{RESULTS AND DISCUSSION}

Compounds 4, 8 were moderately soluble in redistilled water $\left(c=1 \times 10^{-3} \mathrm{~mol} \mathrm{dm}^{-3}\right)$, while compound 7 due to poor aqueous solubility was dissolved in DMSO and used as a stock solution. For accurate measurements fresh solutions were prepared daily.

The UV-Vis spectra of the compounds' aqueous solutions are proportional to their concentration up to 2 $\mu \mathrm{mol} \mathrm{dm}{ }^{-3}$ concentration, molar extinction coefficients are given in Table 1.

Closer analysis of the UV-Vis spectra presented on Figure 1 (collected at $1 \mu \mathrm{mol} \mathrm{dm} \mathrm{d}^{-3}$ concentration to avoid intermolecular aggregation) revealed significant differences between referent $\mathbf{4}$ and conjugates $\mathbf{7}$ and $\mathbf{8}$. Namely, UV-Vis spectrum of referent $\mathbf{4}$ agrees well with the spectrum of free pyrene derivatives in water, ${ }^{[2,4]}$ characterised by three sharply defined maxima between 300-350 nm. However, conjugate 8 revealed strong hypochromic effect and broadening of maxima accompanied by small bathochromic shift $(\Delta \lambda=+3 \mathrm{~nm})$. For conjugate $\mathbf{7}$ hypochromic effect and broadening of maxima was even more pronounced, to the point of merging three maxima in one (in 300-350 nm range). The observed differences could be attributed to the intramolecular

Table 1. Electronic absorption data of 4, 7 and 8 determined from data on Figure 1

\begin{tabular}{lll}
\hline & $\lambda_{\max } / \mathrm{nm}$ & $\varepsilon \times 10^{3} / \mathrm{mmol}^{-1} \mathrm{~cm}^{2}$ \\
\hline 4 & 341 & 34.631 \\
7 & 341 & 7.040 \\
8 & 343 & 18.270 \\
\hline
\end{tabular}




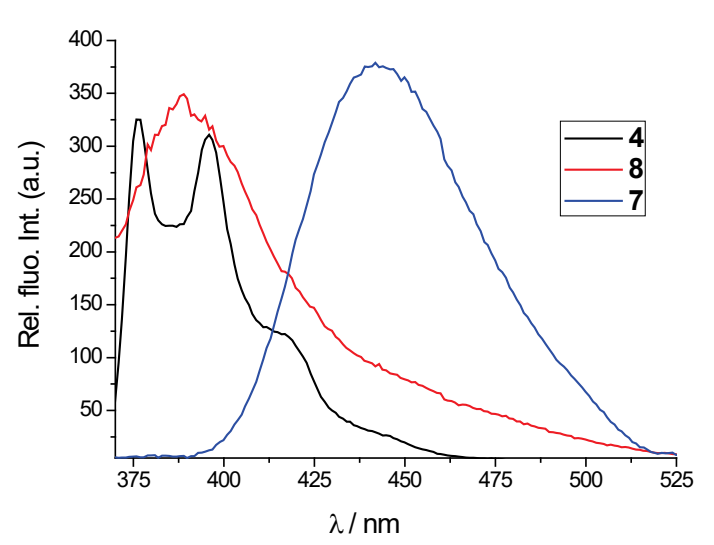

Figure 2. The fluorescence emission spectra of $4,7,8(c=1$ $\mu \mathrm{mol} \mathrm{dm}^{-3}$ ) in buffered solution, $\mathrm{pH}=7$, buffer $\mathrm{Na}$ cacodylate, $I=0.05 \mathrm{M}, \lambda_{\text {exc }}=343 \mathrm{~nm}$.

stacking between pyrene and quinoline, whereby more flexible linker of $\mathbf{8}$ revealed less efficient self - stacking in comparison to more rigid 7 .

These findings were additionally supported by UVVis spectra thermal stability studies by heating to $95{ }^{\circ} \mathrm{C}$, whereby for referent 4 showed negligible changes, conjugate 8 revealed only minor changes, and stronger changes were observed for the $\mathbf{7}$ (Supporting Information).

Aqueous solutions of studied compounds exhibited strong fluorescence emission (Figure 2) upon excitation at pyrene absorbance maximum $\left(\lambda_{\mathrm{exc}}=343 \mathrm{~nm}\right)$. Again, referent 4 exhibited emission spectrum with finely distinguishable vibronic bands $(375,395,417 \mathrm{~nm})$ characteristic for the free pyrene in water. ${ }^{[2,4]}$ The conjugate 8 emission spectrum lost fine vibronic structure and had only one maximum at $390 \mathrm{~nm}$, which could be attributed to partial intramolecular stacking with quinoline. The most intriguing is the emission spectrum of 7 , with one broad maximum bathochromically shifted for about $\Delta \lambda=+$ $60 \mathrm{~nm}$ in respect to $\mathbf{4}$ and $\mathbf{8}$. It is well - known that two pyrenes upon excitation can form aromatically stacked complex - excimer, with characteristic fluorescence emission in the $490-500 \mathrm{~nm}$ range. ${ }^{[4,8]}$ However, conjugate 7 consists of pyrene and quinoline, thus strongly shifted emission maximum could be attributed to pyrene quinoline excimer. Formation of such heterogenic excimer in $\mathbf{7}$ was additionally supported by its emission maximum at $450 \mathrm{~nm}$, whereas pyrene - pyrene excimer emission maximum is at $\lambda>490 \mathrm{~nm}$. ${ }^{[8 \mathrm{~b}]}$

\section{Interactions of 4, 7, 8 with ds - DNA}

Compounds 4, 7 and $\mathbf{8}$ were further studied in buffered solution (sodium cacodylate buffer, $I=0.05 \mathrm{~mol} \mathrm{dm}^{-3}$ ) at $\mathrm{pH}$ $=7$. As a ds - DNA model was used mixed sequence calf

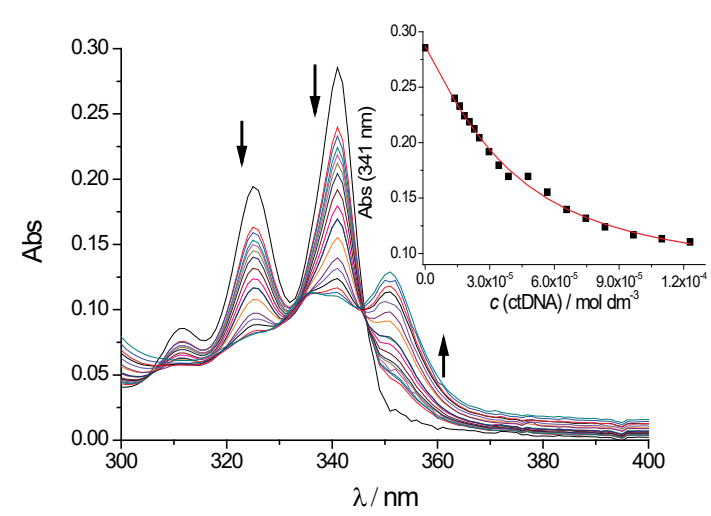

Figure 3. UV-Vis titration of $4\left(\mathrm{c}=1 \times 10^{-5} \mathrm{~mol} \mathrm{dm}^{-3}\right)$ with ct - DNA, $\log K_{\mathrm{s}}=5.3 \mathrm{M}^{-1} ; n_{[\text {bound } 4] /[\mathrm{ctDNA}]}=0.3$. Done at $\mathrm{pH} 7.0$, sodium cacodylate buffer.

thymus ct - DNA, which is characterised by almost equimolar basepair content (42\% GC -; $58 \%$ AT basepairs) and B - helical secondary structure. ${ }^{[14]}$

The UV-Vis titrations were partially hampered by low solubility of compounds and / or their complexes with DNA. Only referent $\mathbf{4}$ yielding the UV-Vis titration data (Figure 3), which could be processed by Scatchard eq. ${ }^{[15]}$ to yield binding constant and Scatchard ratio $n_{\text {[bound dye] / [DNA] }}$.

Detailed analysis of changes in UV-Vis spectrum of $\mathbf{4}$ (Figure 3) or 7 (Supp. Info., done at significantly lower concentrations due to low solubility) revealed that formation of complex with ct - DNA caused strong hypochromic (>50\%) and bathochromic $(\Delta \lambda=+15 \mathrm{~nm})$ effects. Such effects are characteristic for strong aromatic stacking of chromophore, either due to the aromatic interactions with nucleobases or due to the aggregation of chromophores along DNA double helix. To discern between two opposing binding modes, additional methods are needed, which would accurately determine affinity of small molecule to $\mathrm{DNA}^{[15]}$ as well as compound impact on thermal stability ${ }^{[13]}$ and chirality ${ }^{[18]}$ of DNA double helix.

The intrinsic pyrene fluorescence allowed fluorimetric titrations of $\mathbf{4}, \mathbf{7}, \mathbf{8}$ to be performed at much lower concentrations than UV-Vis experiments, thus avoiding solubility problems. In general, fluorescence of studied compounds at their emission maxima was quenched upon addition of ct - DNA. However, each compound showed distinctively different fluorescence change, which would be discussed in detail.

Referent 4 fluorescence (Figure 4A) was almost completely quenched, whereby all maxima similarly decreased with no significant shifting. The conjugate $\mathbf{8}$ showed significantly different emission change (Figure 4B), whereby quenching of pyrene fluorescence at $389 \mathrm{~nm}$ was 


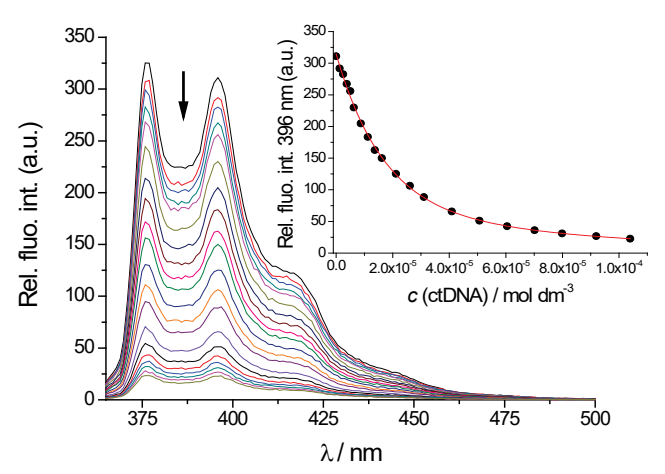

(A)

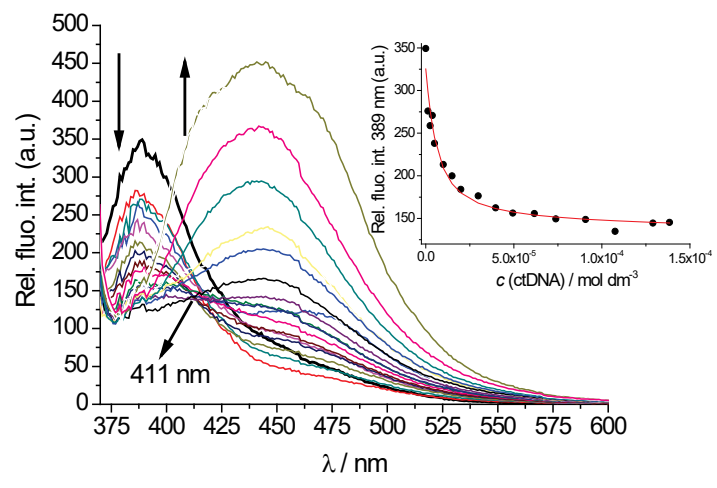

(B)

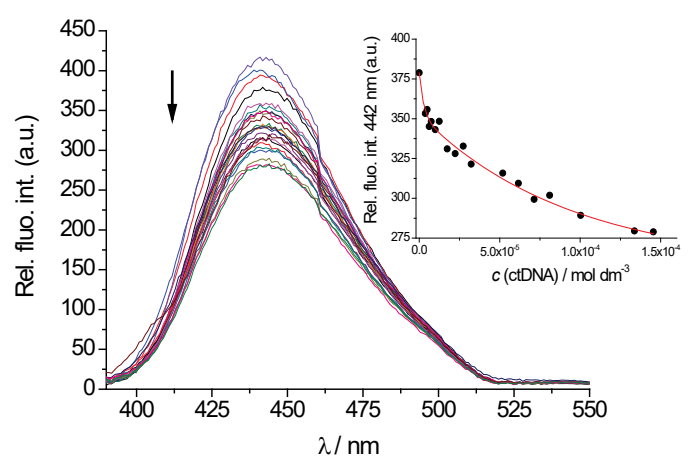

(C)

Figure 4. Changes in fluorescence spectrum of A) 4 ; B) 8 ; C) 7; $\left(c\right.$ (ligand) $\left.=1.0 \times 10^{-6} \mathrm{~mol} \mathrm{dm}^{-3}\right)$ upon titration with ct DNA; $\lambda_{\text {exc }}=343 \mathrm{~nm}$. Insets: Dependence of fluorescence intensity at emission maxima on $c(c t-D N A)$ at $\mathrm{pH}$ 7.0, sodium cacodylate buffer, $I=0.05 \mathrm{~mol} \mathrm{dm}^{-3}$.

accompanied by appearance of a new emission maximum strongly shifted to longer wavelength $(\Delta \lambda=+55 \mathrm{~nm})$. Detailed analysis of titration data revealed that in the range of ratio $r_{[8]} /[$ ctDNA] $=0.5-0.02$ isosbestic point at $411 \mathrm{~nm}$ was evident, thus supporting formation of only one type of $\mathbf{8}$ /
Table 2. Binding constants $\left(\log K_{\mathrm{s}}\right)^{(a)}$ calculated from the fluorescence titrations $\left(\lambda_{\text {exc }}=343 \mathrm{~nm}\right.$ ) of 4,7 and 8 with ct - DNA at $\mathrm{pH}=7.0$ (buffer sodium cacodylate, $l=0.05 \mathrm{~mol} \mathrm{dm}^{-3}$ )

\begin{tabular}{|c|c|c|c|c|}
\hline & & 4 & 7 & 8 \\
\hline & $\log K_{s}^{(a)}$ & $5.5\left(5.3^{(b)}\right)$ & 5.9 & 4.9 \\
\hline \multicolumn{5}{|c|}{$\begin{array}{l}\text { Processing of titration data by means of Scatchard equation }{ }^{[15]} \text { gave values } \\
\text { of ratio } n_{\text {[bound ligand] } / \text { [ct-DNA] }}=0.1-0.3 \text {, for easier comparison all log } K_{\mathrm{s}} \text { values } \\
\text { were re }- \text { calculated for fixed } n=0.3 \text {. Correlation coefficients were }>0.99 \\
\text { for all calculated } K_{\mathrm{s}} \text {. }\end{array}$} \\
\hline & Binding co & nt calculated fr & titrat & \\
\hline
\end{tabular}

DNA complex (these data were processed by Scatchard eq. ${ }^{[15]}$ to give binding constant). Only at large excess of DNA over $8\left(r_{[8]} /[\mathrm{ctDNA}]=0.01-0.001\right)$ the new maximum $\left(\lambda_{\max }=\right.$ $445 \mathrm{~nm}$ ) strongly increased, whereby isosbestic point was lost, pointing out to the appearance of another type of complex. As mentioned before, pyrene excimer fluorescence is characterised by maximum at $490-500$ $\mathrm{nm},{ }^{[8 b]}$ while here observed emission at $445 \mathrm{~nm}$ could be attributed to pyrene - quinoline excimer.

The conjugate $\mathbf{7}$ has intrinsic fluorescence emission maximum at $\lambda=450 \mathrm{~nm}$ since it is in a free state the pyrene - quinoline excimer. Addition of ct - DNA resulted in moderate emission quenching (Figure $4 \mathrm{C}$ ) with preserved shape and maximum of spectrum.

Processing of titration data by means of Scatchard equation ${ }^{[15]}$ yielded binding constants: (Table 2). Excellent agreement of $\log K_{\mathrm{s}}$ values obtained for $\mathbf{4}$ in fluorimetric and UV-Vis titration was noted. In general, all studied compounds showed similar, moderate affinity to ct - DNA.

Thermal denaturation experiments revealed negligible stabilisation of ct - DNA by any of studied compounds (Supp. Info.). That excluded intercalative binding mode, ${ }^{[16]}$ thus suggesting minor groove binding or non - specific electrostatic binding along DNA backbone.

To get better structural insight into $4,7,8-c t-D N A$ complexes, CD spectroscopy was applied as a highly sensitive method for conformational changes in the secondary structure of polynucleotides. ${ }^{[17]}$ Also, achiral small molecule could upon binding to polynucleotides acquire an induced (ICD) spectrum (usually analysed at range > $300 \mathrm{~nm}$ at which DNA / RNA does not absorb), which could be helpful for determination of binding modes (intercalation, agglomeration, groove binding, etc.).[18]

All studied compounds are achiral but intensity of their induced $C D$ spectrum (ICD) in the $230-500 \mathrm{~nm}$ range is negligible with respect to $C D$ spectra of ct - DNA, allowing accurate correction of $C D$ titrations. Addition of 4,8 to ct DNA (Figure 5) did not change significantly CD spectrum of DNA (230 - $300 \mathrm{~nm}$ range) and also no measurable ICD bands were observed ( $300-400 \mathrm{~nm}$ range). Thus, 4,8 do not significantly perturb DNA helicity and their 


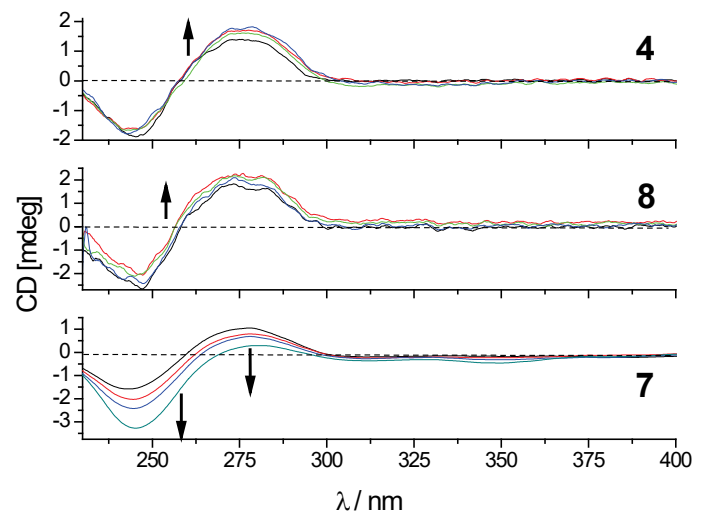

Figure 5. CD titration of $\mathrm{ct}-\mathrm{DNA}\left(c=2 \times 10^{-5} \mathrm{~mol} \mathrm{dm}^{-3}\right)$ with 4,7 and 8 at molar ratios $r_{\text {[compound] } / \text { [polynucleotide] }}=0 ; 0.1 ; 0.2$; 0.3 . Done at $\mathrm{pH} 7$, buffer sodium cacodylate, $I=0.05 \mathrm{~mol}$ $\mathrm{dm}^{-3}$.

chromophores are not uniformly oriented in respect to DNA chiral axis. ${ }^{[18]}$

However, conjugate 7 induced moderate change in CD spectrum of DNA (Figure 5). Namely, in the $230-300 \mathrm{~nm}$ range all signals shifted toward negative values with increasing ratio $r_{\text {[compound] / [polynucleotide] }}$ Such systematic drift in broad wavelength range does not agree with a loss of DNA chirality, which is commonly presented by decrease of the absolute $C D$ band intensity (positive $C D$ band at $280 \mathrm{~nm}$ becoming less positive and negative $C D$ band at $245 \mathrm{~nm}$ becoming less negative). ${ }^{[18]}$ Such systematic drift in CD spectrum is most likely caused by negative induced ICD band of $\mathbf{7}$, which absorbs light in corresponding region (Figure 1). Surprisingly, no significant ICD band in 300-400 $\mathrm{nm}$ range was observed. Taking into account that $\mathbf{7}$ has intramolecularly stacked pyrene and quinoline, obviously principal electronic transitions of such dimeric chromophore in 230-290 $\mathrm{nm}$ range are well oriented in respect to DNA chiral axis. Since DNA minor groove can easily accommodate aromatic stacked dimers ${ }^{[18]}$ and also ICD bands of small molecules in minor groove are usually of strong intensity, minor grove of ct - DNA is most likely binding site of $\mathbf{7}$.

\section{CONCLUSIONS}

Two novel pyrene - quinoline conjugates (7 and 8), showed by their spectrophotometric characteristics to be intramolecularly pre - organised in aqueous solutions, if compared to referent pyrene analogue 4 . Namely, more rigid 7 in water formed intramolecular pyrene - quinoline stacked conformation, characterised by strong hypochromic UV-Vis effect and typical fluorescence of pyrene - quinoline excimer. More flexible linker in conjugate $\mathbf{8}$ did not allow such efficient intramolecular stacking as 7 , thus exhibiting much weaker hypochromic UV-Vis effect and only free pyrene fluorescence.

Particularly interesting are fluorimetric titrations results. Pre-organised pyrene - quinoline dimer 7 retained its intramolecular stacking upon DNA binding, thus its characteristic fluorescence only weakly quenched. The pyrene fluorescence of $\mathbf{8}$ was almost completely quenched (similarly to referent 4); however, at large excess of DNA over 8 new fluorophore entity was formed within DNA binding site, with fluorescence characteristic for pyrene quinoline excimer.

All compounds $(4,7,8)$ bind moderately strong to ct - DNA (by $10 \mu \mathrm{mol} \mathrm{dm}^{-3}$ affinity) but do not stabilise DNA against thermal denaturation and do not perturb DNA chirality. In addition, CD results suggest that $\mathbf{4}$ and $\mathbf{8}$ chromophores are not uniformly oriented in respect to DNA chiral axis, all data taken together excluding intercalation of typical minor groove binding. Thus, $\mathbf{4}$ and $\mathbf{8}$ bind by non - organised agglomeration within hydrophobic DNA grooves. At variance to them, $\mathbf{7}$ showed considerable impact on $C D$ spectrum, attributed to ICD band of intramolecular pyrene - quinoline dimer positioned uniformly within DNA minor groove. ${ }^{[18]}$

Here presented results can find applications in supramolecular chemistry, as well as in medicinal chemistry relying on innovative and versatile spectrophotometric probes with fine tuning of intra - and intermolecular interactions. For instance, further in vitro studies on a panel of human cell lines would give an insight in intracellular distribution and fluorimetric response of these fluorophores.

Acknowledgment. Authors gratefully acknowledge financial support of ESF project HR.3.2.01 - 0254. IP and IO thank Croatian Science Foundation project 1477 for financial support.

\section{REFERENCES}

[1] M. Demeunynck, C. Bailly, W. D. Wilson, Small Molecule DNA and RNA Binders: From Synthesis to Nucleic Acid Complexes, Wiley-VCH Verlag GmbH \& Co. KGaA, Weinheim, 2004.

[2] a) F. M. Winnik, Chem. Rev. 1993, 93, 587; b) K. Kalyanasundaram, J. K. Thomas, J. Am. Chem. Soc. 1977, 99, 2039; c) D. C. Dong, M. A. Winnik, Photochem. Photobiol. 1982, 35, 17.

[3] a) J. R. Lakowicz, Principles of Fluorescence Spectroscopy, Kluwer Academic/Plenum, New York, 1999; b) F. M. Winnik, Chem. Rev. 1993, 93, 614; c) S. S. Lehrer, Methods Enzymol. 1997, 278, 286. 
[4] a) P. C. Bevilacqua, R. Kierzek, K. A. Johnson, D. H. Turner, Science 1992, 258, 1358; b) K. Yamana, T. Gokota, H. Ozaki, H. Nakano, O. Sangen, T. Shimidzu, Nucleosides Nucleotides 1992, 11, 383; c) R. Kierzek, Y. Li, D. H. Turner, P. C. Bevilacqua, J. Am. Chem. Soc. 1993, 115, 4985; d) Y. Li, P. C. Bevilacqua, D. Mathews, D. H. Turner, Biochemistry 1995, 34, 14394; e) M. Manoharan, K. L. Tivel, M. Zhao, K. Nafisi, T. L. Netzel, J. Phys. Chem. 1995, 99, 17461; f) J. Yguerabide, E. Talavera, J. M. Alvarez, M. Afkir, Anal. Biochem. 1996, 241, 238; g) J. Dapprich, N. G. Walter, F. Salingue, H. Staerk, J. Fluoresc. 1997, 7, 87; h) R. Preuß, J. Dapprich, N. G. Walter, J. Mol. Biol. 1997, 273, 600; i) K. Yamana, R. Iwase, S. Furutani, H. Tsuchida, H. Zako, T. Yamaoka, A. Murakami, Nucleic Acids Res. 1999, 27, 2387; j) S. K. Silverman, T. R. Cech, Biochemistry 1999, 38, 14224; k) K. Yamana, H. Zako, K. Asazuma, R. Iwase, H. Nakano, A. Murakami, Angew. Chem. 2001, 113, 1138; Angew. Chem. Int. Ed. 2001, 40, 1104; I) V. A. Korshun, D. A. Stetsenko, M. J. Gait, J. Chem. Soc. Perkin Trans 1 2002, 1092.

[5] a) H. Fritzsche, A. Akhebat, E. Taillandier, K. Rippe, T. M. Jovin, Nucleic Acids Res. 1993, 21, 5085; b) K. Ebata, M. Masuko, H. Ohtani, M. Kashiwasake-Jibu, Photochem. Photobiol. 1995, 62, 836; c) G. Tong, J. M. Lawlor, G. W. Tregear, J. Haralambidis, J. Am. Chem. Soc. 1995, 117, 12151; d) F. D. Lewis, Y. Zhang, R. L. Letsinger, J. Am. Chem. Soc. 1997, 119, 5451; e) K. V. Balakin, V. A. Korshun, I. A. Prokhorenko, G. V. Maleev, I. A. Kudelina, S. V. Gontarev, Y. A. Berlin, Bioorg. Khim. 1997, 23, 33; f) P. L. Paris, J. M. Langenhan, E. T. Kool, Nucleic Acids Res. 1998, 26, 3789; g) K. V. Balakin, V. A. Korshun, I. I. Mikhalev, G. V. Maleev, A. D. Malakhov, I. A. Prokhorenko, Y. A. Berlin, Biosens. Bioelectron. 1998, 13, 771; h) M. Masuko, H. Ohtani, K. Ebata, A. Shimadzu, Nucleic Acids Res. 1998, 26, 5409; i) V. A. Korshun, K. V. Balakin, T. A. Proskurina, I. I. Mikhalev, A. D. Malakhov, Y. A. Berlin, Nucleosides Nucleotides 1999, 18, 2661; j) E. Kostenko, M.
Dobrikov, D. Pyshnyi, V. Petyuk, N. Komarova, V. Vlassov, M. Zenkova, Nucleic Acids Res. 2001, 29, 3611; k) A. Mahara, R. Iwase, T. Sakamoto, K. Yamana, T. Yamaoka, A. Murakami, Angew. Chem. 2002, 114, 3800; Angew. Chem. Int. Ed. 2002, 41 , 3648.

[6] a) B. Ravindra Babu, A. K. Prasad, S. Trikha, N. Thorup, V. S. Parmar, J. Wengel, J. Chem. Soc. Perkin Trans 1, 2002, 22, 2509; c) U. B. Christensen, E. B. Pedersen, Nucleic Acids Res. 2002, 30, 4918; d) V. V. Filichev, E. B. Pedersen, Org. Biomol. Chem. 2003, 1, 100; e) J. Michel, K. Bathany, J.-M. Schmitter, J.-P. Monti, S. Moreau, Tetrahedron 2002, 58, 7975.

[7] K. Groger, D. Baretić, I. Piantanida, M. Marjanović, M. Kralj, M. Grabar, S. Tomić, C. Schmuck, Org. Biomol. Chem. 2011, 9, 198.

[8] a) L. Hernandez-Folgado, C. Schmuck, S. Tomić, I. Piantanida, Bioorg. Med. Chem. Lett. 2008, 18, 2977; b) J. C. Wu, Y. Zou, C. Y. Li, W. Sicking, I. Piantanida, T. Yi, C. Schmuck, J. Am. Chem. Soc. 2012, 134, 1958.

[9] J. Matić, L.-M. Tumir, M. Radić Stojković, I. Piantanida, Curr. Prot. Pep. Sci. 2016, 17, 127.

[10] J. Suć, L. M. Tumir, L. Glavaš-Obrovac, M. Jukić, I. Piantanida, I. Jerić, Org. Biomol. Chem. 2016, 14, 4865.

[11] L. Delauriere, Z. Y. Dong, K. Laxmi-Reddy, F. Godde, J. J. Toulme, I. Huc, Angew. Chem. - Int. Ed. 2012, 51, 473.

[12] I. Piantanida, B. S. Palm, P. Čudić, M. Žinić and H. J. Schneider, Tetrahedron 2004, 60, 6225.

[13] J. L. Mergny, L. Lacroix, Oligonucleotides 2003, 13, 515.

[14] C. R. Cantor, P. R. Schimmel, Biophysical Chemistry, W.H. Freeman and Co., San Francisco, 1980.

[15] J. D. McGhee, P. H. V. Hippel, J. Mol. Biol. 1974, 86, 469; G. Scatchard, N. Y. Ann, Acad. Sci. 1949, 51, 660.

[16] E. C. Long, J. K. Barton, Acc. Chem. Res. 1990, 23, 271.

[17] A. Rodger, B. Norden, Circular Dichroism and Linear Dichroism, Oxford University Press, New York, 1997.

[18] M. Eriksson, B. Nordén, Methods in Enzymology, Academic Press, San Diego, 2001. 